\title{
Neurobiology of COVID-19: how can the virus affect the brain?
}

\author{
Jaqueline S. Generoso, ${ }^{1}$ iD João L. Barichello de Quevedo, ${ }^{1}$ Matias Cattani, ${ }^{1}$ Bruna F. Lodetti, ${ }^{1}$ \\ Lucas Sousa, ${ }^{1}$ Allan Collodel, ${ }^{1}$ iD Alexandre P. Diaz, ${ }^{2}$ iD Felipe Dal-Pizzol ${ }^{1}$ iD \\ ${ }^{1}$ Laboratório de Fisiopatologia Experimental, Programa de Pós-Graduação em Ciências da Saúde, Universidade do Extremo Sul Catarinense, \\ Criciúma, SC, Brazil. ${ }^{2}$ Louis A. Faillace, MD, Department of Psychiatry and Behavioral Sciences, University of Texas Health Science Center at \\ Houston, Houston, TX, USA.
}

\begin{abstract}
Severe acute respiratory syndrome-related coronavirus-2 (SARS-CoV-2) causes the coronavirus disease 2019 (COVID-19), which has been declared a public health emergency of international interest, with confirmed cases in most countries. COVID-19 presents manifestations that can range from asymptomatic or mild infections up to severe manifestations that lead to hospitalization and death. A growing amount of evidence indicates that the virus may cause neuroinvasion. Postmortem brain study findings have included edema, hemorrhage, hydrocephalus, atrophy, encephalitis, infarcts, swollen axons, myelin loss, gliosis, neuronal satellitosis, hypoxic-ischemic damage, arteriolosclerosis, leptomeningeal inflammation, neuronal loss, and axon degeneration. In addition, the COVID-19 pandemic is causing dangerous effects on the mental health of the world population, some of which can be attributed to its social impact (social distancing, financial issues, and quarantine). There is also a concern that environmental stressors, enhanced by psychological factors, are contributing to the emergence of psychiatric outcomes during the pandemic. Although clinical studies and diagnosing SARS-CoV-2-related neurological disease can be challenging, they are necessary to help define the manifestations and burden of COVID-19 in neurological and psychiatric symptoms during and after the pandemic. This review aims to present the neurobiology of coronavirus and postmortem neuropathological hallmarks.
\end{abstract}

Keywords: Coronavirus-2; COVID-19; SARS-CoV-2; neurobiology; psychiatric disorders

\section{Introduction}

Emerging pathogens have become significant challenges for public health worldwide. ${ }^{1}$ Coronaviruses are enveloped viruses with RNA as genetic material. They are commonly found among humans, other mammals, and birds. In some species, the virus can cause diseases in the respiratory tract, intestinal tract, and liver, as well as neurological disorders in humans. ${ }^{2}$ By 2019 , two viruses of the coronavirus family had caused major epidemic outbreaks of respiratory diseases: severe acute respiratory syndrome (SARS), from 2002 to 2004, and the Middle East respiratory syndrome (MERS) in 2012. ${ }^{3}$ At the end of December 2019, the World Health Organization $(\mathrm{WHO})$ was notified that in Wuhan, China, cases of pneumonia of unknown etiology 4 were occurring and spreading rapidly to other parts of China, Asia, Europe, and later to the Americas. ${ }^{5}$ In January 2020, the virus was isolated from airway epithelial cells of patients affected by the disease. The etiologic agent was identified as a new coronavirus; however, it was different from severe acute

Correspondence: Jaqueline S. Generoso, Laboratório de Fisiopatologia Experimental, Programa de Pós-Graduação em Ciências da Saúde, Universidade do Extremo Sul Catarinense, Av. Universitária, 1105, Bairro Universitário, CEP 88806-000 Criciúma, SC, Brazil. E-mail: jsg@unesc.net

Submitted Sep 07 2020, accepted Dec 09 2020, Epub Feb 102021. respiratory syndrome coronavirus (SARS-CoV) and Middle East respiratory syndrome coronavirus (MERS-CoV). ${ }^{6}$ The new virus was named severe acute respiratory syndrome-related coronavirus-2 (SARS-CoV-2) ${ }^{7}$ and it causes coronavirus disease 2019 (COVID-19). The COVID-19 pandemic, with confirmed cases in most countries, has been declared a public health emergency of international interest. ${ }^{8}$ COVID-19 symptoms range from asymptomatic or mild infections (approximately $80 \%$ ) to severe signs that lead to hospitalization and death. ${ }^{9}$ Transmission occurs from person to person mainly through respiratory droplets, which are usually released when the infected person coughs or sneezes, and direct contact, similar to the human influenza virus, SARS-CoV and MERS-CoV. ${ }^{8}$ To a lesser extent, transmission can occur through contaminated surfaces. ${ }^{10}$ However, recent evidence supports that transmission can also occur via aerosols, mostly indoors where there is insufficient ventilation and long-term exposure to high concentrations of aerosols. ${ }^{11,12}$ The approximate incubation period from exposure to symptom onset is 4 to

How to cite this article: Generoso JS, Barichello de Quevedo JL, Cattani M, Lodetti BF, Sousa L, Collodel A, et al. Neurobiology of COVID-19: how can the virus affect the brain? Braz J Psychiatry. 2021;43:650-664. http://dx.doi.org/10.1590/1516-4446-2020-1488 
6 days, $^{12,13}$ and $97.5 \%$ of symptomatic patients have symptoms within 11 days of infection. ${ }^{12}$ The most frequent clinical symptoms are fever, dry cough, fatigue, dyspnea, anosmia, ageusia, gastrointestinal symptoms, or some combination of these. ${ }^{14}$ Shortness of breath usually occurs between 5 to 8 days after the first symptoms and is suggestive of disease worsening. ${ }^{14,15}$ Risk factors for COVID-19 complications include old age ( $>65$ years), cardiovascular disease, chronic lung disease, hypertension, diabetes, obesity, ${ }^{16}$ and autoimmune diseases (rheumatoid arthritis, lupus, or psoriasis). ${ }^{17}$ By December 2020, more than 67.2 million cases had been confirmed worldwide, resulting in more than 1.5 million deaths. ${ }^{18}$ According to the WHO report, more than 26.2 million cases and 720,228 deaths have been confirmed in the Americas; in Europe, there have been more than 18.4 million cases and 412,362 deaths; in Southeast Asia, there have been more than 10.7 million cases and 163,454 deaths; in the Mediterranean there have been more than 4.04 million cases and 102,160 deaths; in Africa there have been over 1.4 million cases and 33,512 deaths; and in the Western Pacific there have been over 800,000 cases and 17,261 deaths. $^{19}$ This review aims to present the neurobiology of the coronavirus and its postmortem neuropathological hallmarks.

The coronavirus: severe acute respiratory syndromerelated coronavirus 2 (SARS-CoV-2)

Although scientists have developed precise techniques and have quickly identified the new coronavirus, it is necessary to investigate its viral structure, colonization and pathogenic mechanisms, and the future consequences of infection on survivors. ${ }^{20}$

SARS-CoV-2 is a spherical $\beta$-coronavirus that received this name due to its high similarity to SARS-CoV (79.5\%). Since they belong to the same family, Coronaviridae, they share several similarities. ${ }^{21}$ SARS-CoV-2 is an enveloped virus with a single-stranded positive RNA genome of approximately $30 \mathrm{~kb}$, with a receptor-binding domain (RBD) structure similar to that of SARS-CoV. ${ }^{22}$ Open reading frames (ORFs) ORF1a and ORF1b have also been identified in its sequencing, which encode a variety of structural and non-structural proteins that play an essential role in viral survival and virulence power. ${ }^{23}$ The four structural proteins encoded by ORFs include spike (S) proteins, membrane (M) proteins, nucleocapsid (N) proteins, and envelope (E) proteins, ${ }^{24}$ which are all necessary to produce a structurally complete viral particle $^{25}$ (Figure 1).

Protein $S$ is a highly immunogenic homotrimeric glycoprotein (ranging from 9 to $12 \mathrm{~nm}$ ) in the outer portion of the virus, which gives the appearance of a solar corona. ${ }^{26}$ It is one of the main targets of neutralizing antibodies after host infection and therapeutic and vaccine focus. ${ }^{27}$ This protein is essential for virus fixation on the surface of host cells, where the RBD of protein $S$ mediates the interaction with angiotensin-converting enzyme 2 (ACE2). ${ }^{28}$ There are two functional subunits of this protein: the $S 1$ subunit, which is responsible for binding to the host cell's receptor, and the S2 subunit, which is responsible for fusion between the viral and cellular membranes, facilitating viral entry into the cell. ${ }^{27}$ Protein $S$ can access the endoplasmic reticulum using an $\mathrm{N}$-terminal signal sequence, and it is strongly associated with glycosylated N.29

Another essential component of SARS-CoV-2 is protein M. This approximately $25-30 \mathrm{kDa}$ protein is the most abundant in the virus, can bind to all other structural proteins, and is responsible for defining the shape of the viral envelope. ${ }^{30}$ The interaction between $M$ and $N$ proteins can stabilize and form nucleocapsids, promoting completion of viral assembly. ${ }^{31}$ Protein $M$ exists as a dimer and can have two conformations: MLONG, which is

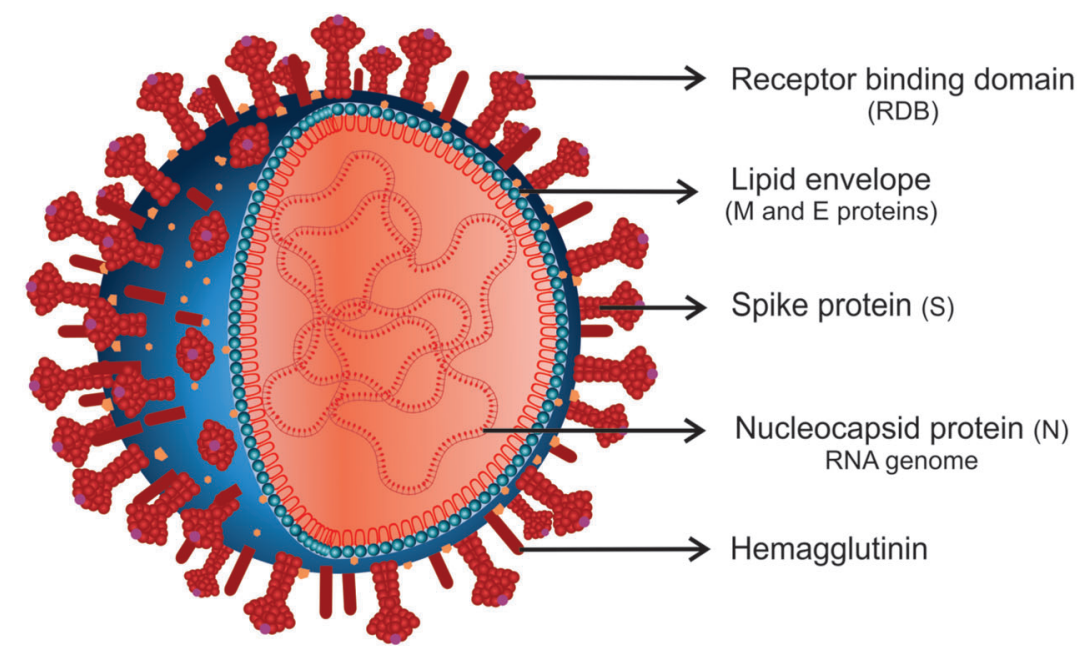

Figure 1 Schematic representation of new coronavirus structure. Severe acute respiratory syndrome-related coronavirus-2 (SARS-CoV-2) is a spherical $\beta$-coronavirus with a positive-sense RNA with four main structural proteins: spike (S) and membrane (M) glycoproteins, as well as envelope (E) and nucleocapsid (N) proteins. The receptor-binding domain (RBD) of protein $S$ interacts with angiotensin-converting enzyme 2 (ACE2) on the surface of host cells. 
associated with rigidity, spike clusters and the curvature of the membrane, and $\mathrm{M}_{\text {СOMPACT, which is associated }}$ with flexibility and low spike density. ${ }^{32}$ In addition, the interaction between $M$ and $S$ is essential for the fixation of $S$ in the endoplasmic reticulum - Golgi intermediate compartment/Golgi complex and its incorporation into new virions. ${ }^{33}$

The $\mathrm{N}$ protein, another structural protein of the virus, consists of two domains: an $\mathrm{N}$-terminal domain and a C-terminal domain. ${ }^{31}$ This protein is closely linked to the genetic material forming the nucleocapsid. It is thus involved in processes related to the viral genome, such as RNA transcription and replication, and the response of host cells to viral infections. ${ }^{34,35}$ It is also involved in assembly and viral budding, resulting in the complete formation of the virion. ${ }^{36}$ Protein $\mathrm{N}$ is still intensely phosphorylated and can generate structural changes, increasing affinity for viral RNA. ${ }^{33}$

The last and smallest structural component is protein $\mathrm{E}$ ( 8 to $12 \mathrm{kDa}$ ), which has a role in viral production and maturation. ${ }^{37}$ This membrane protein has ion channel activity with an N-terminal ectodomain and a C-terminal endodomain. ${ }^{36}$ Proteins $E, M$, and $S$ are incorporated into the lipid envelope of the virion. While protein $S$ is involved in fusion with host membranes and protein $M$ in envelope formation and budding, protein $E$ is not essential for virus replication. However, if it is absent, it can result in virus attenuation and prejudice viral maturation. ${ }^{38}$

\section{The mechanism of pathogenicity}

Many aspects of the pathogenesis of COVID-19 must be understood. Fundamental processes in the life cycle of SARS-CoV-2 in the host include binding, penetration, biosynthesis, maturation, and release. Upon invasion, the virus binds to the host's receptors (binding) and enters cells through endocytosis or membrane fusion (penetration). Afterward, the viral content is released, and the viral RNA enters the cell's nucleus for replication. The viral mRNA is soon copied and used for the production of viral proteins (biosynthesis), and new viruses are organized (maturation) and released. ${ }^{39}$

Reports of devastating damage to the cardiovascular system, intestines, kidneys, and brain in COVID19 patients have surfaced more frequently. ${ }^{40}$ Blood coagulation can constrict the vessels, resulting in pulmonary embolism, ischemic stroke, or ischemia in the extremities. ${ }^{40,41}$

The host cell infection mechanism of SARS-CoV-2 is similar to that of SARS-CoV; it is mediated mainly by the ACE2 cell surface receptor ${ }^{42}$ and less frequently by CD147. ${ }^{23}$ ACE2 is a glycoprotein expressed in the epithelium of the airways, lungs parenchyma, vascular endothelium, heart, kidneys, and small intestine. ${ }^{43}$ However, ACE2 receptors are also expressed in regions of the human brain, such as the motor cortex and posterior cingulate, nigra substance, ventricles, middle temporal gyrus, olfactory bulb, ventrolateral medulla, solitary tract nucleus, and vagus nerve. Some central nervous system (CNS) cells, including neurons, microglia, astrocytes, and oligodendrocytes, can also express ACE2 ${ }^{43,44}$
SARS-CoV-2 can access the CNS can occur in two ways: hematogenous dissemination or the neural pathway. ${ }^{45}$ Hematogenous dissemination occurs through leukocytes, which serve as a dissemination vehicle for the CNS through the blood-brain barrier (BBB) or bloodcerebrospinal fluid barrier. ${ }^{46}$ Access to the CNS can occur by expressing ACE2 in vascular endothelial cells ${ }^{44}$ or by infected leukocytes that cross the BBB, which is known as a Trojan horse mechanism. ${ }^{46}$ The intense inflammatory response of COVID-19 can lead to increased permeability of the BBB, allowing infected cells, cytokines, and even the virus to pass into the CNS. ${ }^{47}$ Neural access involves transporting the virus through the nasal cavity and rhinopharynx through the olfactory and trigeminal nerves, while the lower respiratory tract is accessed through the vagus nerve. ${ }^{48}$ The virus then spreads via transsynaptic transfer using endocytosis/exocytosis and the vesicle's fast axonal transport mechanism to move along microtubules to neuronal cell bodies ${ }^{44}$ (Figure 2).

To enter cells, SARS-CoV-2 uses protein $S$ to bind to the ACE2 receptor via the RBD of the $S 1$ subunit. ${ }^{20}$ Therefore, viral internalization is facilitated by type 2 transmembrane serine protease (TMPRSS2), which cleaves ACE2 and the S1/S2 subunit site and allows the fusion of the viral and cellular membranes, a process carried out by the $\mathrm{S} 2$ subunit. ${ }^{49}$ The virus enters the host cell by endocytosis, releases its genetic material and uses its machinery to translate and replicate RNA and release new viruses ${ }^{42}$ (Figure 3).

The host's immune system can detect SARS-CoV-2 through viral RNA, glycoproteins, and other virus molecules, also known as pathogen-associated molecular patterns. ${ }^{50}$ These patterns are recognized by pattern recognition receptors, such as Toll-like receptors, which are present in antigen-presenting cells, such as macrophages and monocytes. ${ }^{51}$ Protein $S$ can be recognized by TLR $4^{52}$ and, after recognition, intracellular signaling begins through signal transmission from the cytoplasmic domain of the TLR to interleukin-1 receptor-associated with kinase 4 (IRAK-4). ${ }^{53}$ IRAK-4 activation is mediated by myeloid differentiation protein 88 . IRAK- 4 stimulates tumor necrosis factor receptor-associated factor 6 , and this cascade results in the release of the nuclear transcription factor-kappa $B$ and the mitogen-activated protein kinase pathway, which activates gene expression of proinflammatory molecules, such as tumor necrosis factor-alpha (TNF- $\alpha$ ), interleukin (IL)-1 $\beta$, IL-6, IL-8, IL-33, interferon (IFN)- $\alpha$, IFN- $\gamma$, and chemokines. ${ }^{30}$ During viral replication, endosomal receptors TLR3 and TLR7 can also recognize viral RNA, resulting in nuclear activation and translocation of interferon regulatory factor-3 and nuclear transcription factor-kappa $B$, which induces the production of type I IFN (IFN- $\alpha$ ) and proinflammatory cytokines. ${ }^{54}$ After release, IFN- $\alpha$ can bind to IFN- $\alpha / \beta$ receptor, activate the Janus kinase pathway and the signal transducer and activator of transcription (STAT), STAT1 and STAT2, which form complexes with interferon regulatory factor-9, initiating the transcription of IFN-stimulated genes. Together, the expression of cytokines, IFNs, and IFN-stimulated genes establish an innate immune response that prevents viral replication in 

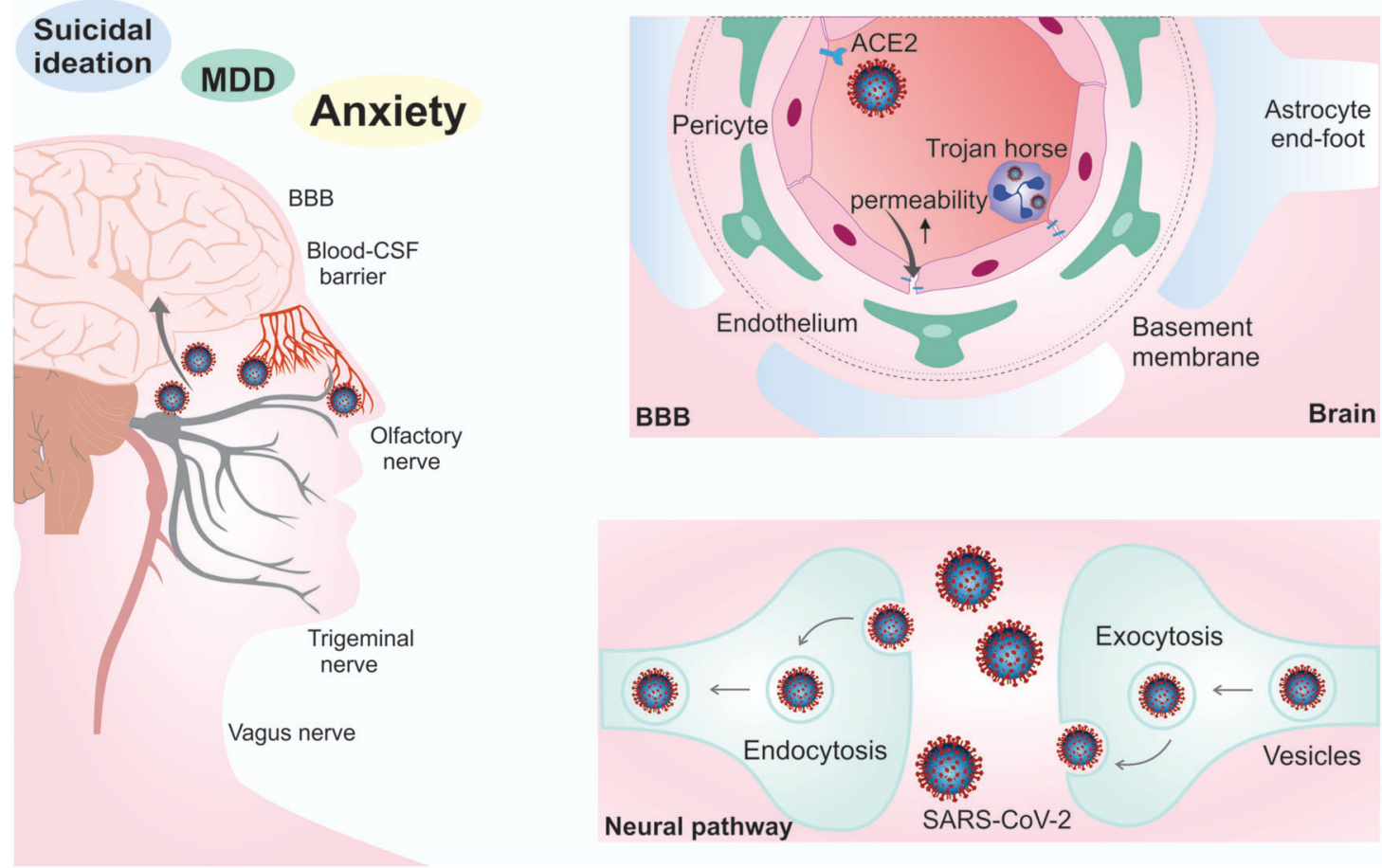

Figure 2 Mechanisms of central nervous system entry. Access to the central nervous system (CNS) through the blood-brain barrier (BBB) can occur by expressing angiotensin-converting enzyme 2 (ACE2) in vascular endothelial cells or by infected leukocytes that cross through the BBB, known as a Trojan horse mechanism (hematogenous pathway). Neural access involves transporting the virus through the nasal cavity and rhinopharynx through the olfactory and trigeminal nerves and the lower respiratory tract through the vagus nerve (neural pathway). $\mathrm{CSF}=$ cerebrospinal fluid; $\mathrm{MDD}=$ major depressive disorder; SARS-CoV-2 = severe acute respiratory syndrome-related coronavirus-2.

infected cells ${ }^{54,55}$ (Figure 3). However, the coronavirus has developed strategies to survive in host cells, including the formation of vesicles that prevent recognition by pattern recognition receptors and the use of structural and non-structural proteins that can suppress the activation of IFNs, which are closely associated with disease severity. ${ }^{56}$

\section{Post-mortem brain studies}

Autopsy tissue samples are essential to understanding the effect and consequences of COVID-19 on the brain. Here we report the results of autopsies of brain samples from patients who died of COVID-19. The following areas of the brain were studied in the reviewed papers: the frontal and occipital lobes, olfactory bulb, cingulate gyrus, corpus callosum, hippocampus, basal ganglia, thalamus, cerebellum, midbrain, pons, medulla, neocortex, brainstem, gyrus rectus, cerebral and cerebellar white and grey matter, and the lateral ventricles. Macroscopically, the studies revealed the presence of edema, ${ }^{57-59}$ hemorrhagic lesions, ${ }^{57-62}$ hydrocephalus, ${ }^{63}$ atrophy,${ }^{64}$ low brain weight, ${ }^{65}$ encephalitis, ${ }^{66}$ asymmetry in the olfactory bulb, ${ }^{58}$ and infarcts. ${ }^{67,68}$ Microscopically, the results included positive astrocyte reactivity evaluated for GFAP, swollen axons $^{57}$ and loss of myelin, ${ }^{57,62}$ gliosis and neuronal satellitosis, ${ }^{69}$ hypoxic-ischemic damage, ${ }^{67,68,70}$ mild or moderate arteriolosclerosis, leptomeningeal inflammation, microglial nodules, ${ }^{67}$ neuron loss, ${ }^{66,71}$ axon degeneration, ${ }^{62,66}$ diffuse or focal spongiosis, vascular congestion, and focal ischemic necrosis. ${ }^{59}$ For more details about the post-mortem brain studies, see Table 1.

\section{Neurological manifestations of coronavirus}

As the SARS-CoV-2 pandemic progresses, a growing body of evidence indicates that the virus can cause neuroinvasion and affect the CNS in several ways. ${ }^{79,80}$ The virus can gain access to the CNS via the neural pathway (olfactory nerve and nasal cavity) or the hematogenous pathway (infected leukocytes and endothelial cells from the BBB). ${ }^{44,45}$ Neurotropism is also a common feature of the SARS-CoV and MERS-CoV viruses, and it has been reported that the endothelium, glial cells, and neurons express ACE2, which makes them a potential target for SARS-CoV-2. ${ }^{81}$

Neurological manifestations during COVID-19 infection can be caused directly by the virus in the CNS or by the host's immune response and systemic complications. ${ }^{79}$ After gaining access to the CNS, the virus can cause immune cell infiltration and activate inflammatory pathways through the secretion of cytokines and chemokines and activate thrombotic pathways, which contribute to tissue damage and cause microangiopathy, respectively. ${ }^{79,82}$ Nonspecific symptoms include headache, dizziness, anosmia, ageusia, hypoplasia, and neuralgia (the latter four involving cranial nerves), ${ }^{47}$ in addition to sleep disorders, stroke, impaired consciousness, coma, 


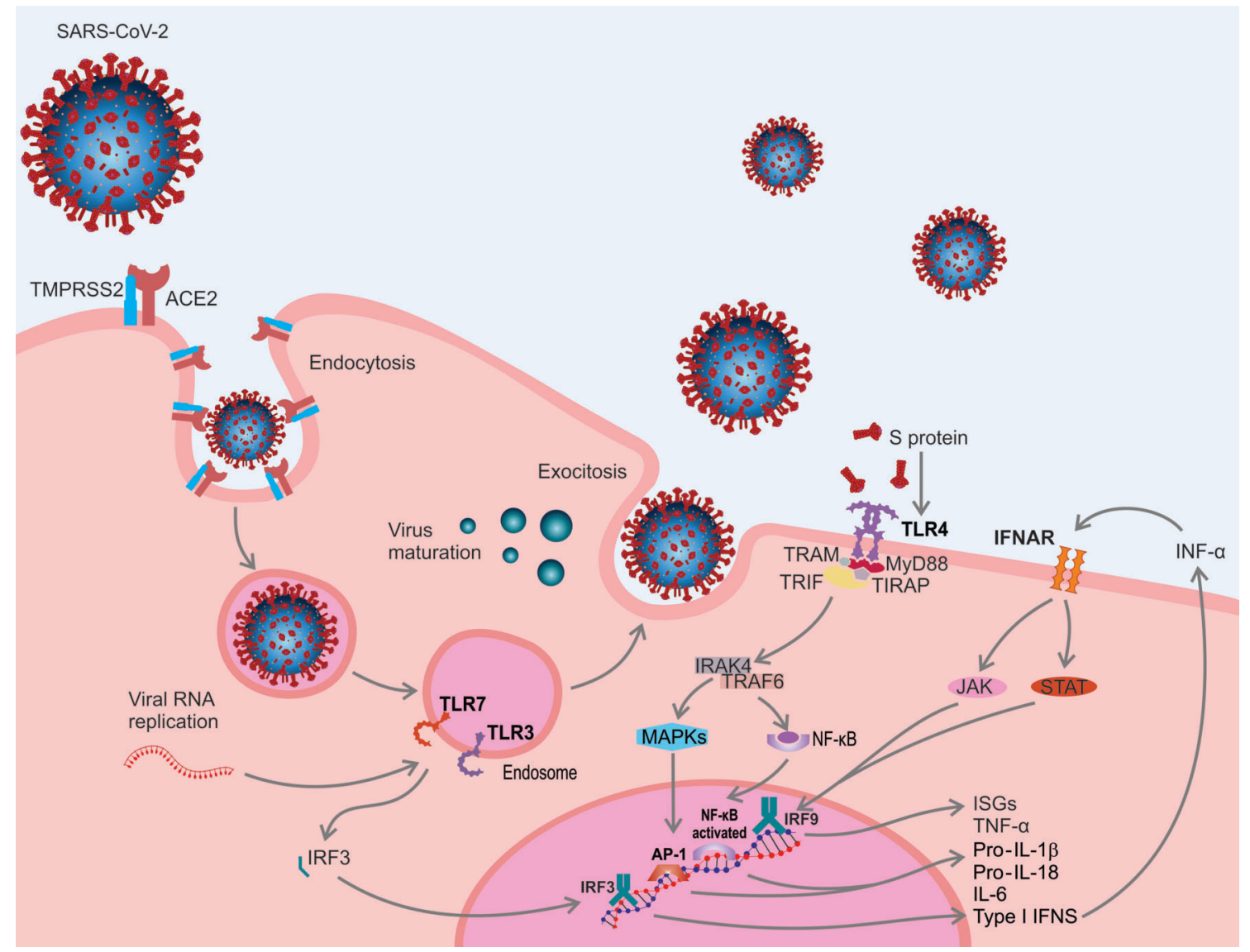

Figure 3 Severe acute respiratory syndrome-related coronavirus-2 (SARS-CoV-2) entry and pathophysiology of coronavirus disease 2019 (COVID-19): 1) to enter inside of the cells, SARS-CoV-2 uses spike protein (S) to bind to the angiotensinconverting enzyme 2 (ACE2) receptor via the receptor-binding domain (RBD). Viral internalization is facilitated by type 2 transmembrane serine protease (TMPRSS2), which allows the fusion of the viral and cellular membranes. The virus enters the host cell by endocytosis, releases its genetic material, and uses its machinery to translate and replicate RNA and release new viruses; 2) recognition of pathogen-associated molecular patterns (PAMPs), including viral RNA and glycoproteins, by pattern recognition receptors (PRRs), such as Toll-like receptor (TLR)3, 4 and 7 ; 3) after recognition, cell signaling begins with the transmission of the signal from the cytoplasmic domain of the TLR to receptor-associated with kinase 4 (IRAK-4), which is mediated by myeloid differentiation protein 88 (MyD88). Afterwards, nuclear transcription factor kappa B (NF-kB) and mitogenactivated protein kinases (MAPKs) activate genes for proinflammatory molecule expression, including tumor necrosis factoralpha (TNF- $\alpha$ ), interleukin (IL)-1 $\beta$, IL-6, IL-18, and interferon-alpha (IFN- $\alpha$ ); 4) TLR3 and TLR7 recognize viral RNA, resulting in nuclear activation and translocation of interferon regulatory factor 3 (IRF3) and NF-KB, which induce the production of IFN- $\alpha$ and proinflammatory cytokines. IFN- $\alpha$ can bind to the IFN- $\alpha / \beta$ receptor (IFNAR), activate the Janus kinase pathway (JAK) and signal transducer and activator of transcription (STAT), initiating the transcription of IFN-stimulated genes (ISGs); 5) the expression of proinflammatory mediators establish an innate immune response. TIRAP $=$ Toll-interleukin 1 receptor (TIR) domain-containing adaptor protein; TRAF6 = tumor necrosis factor receptor-associated factor 6; TRAM = TRIF-related adaptor molecule; TRIF = TIR-domain-containing adapter-inducing interferon- $\beta$.

seizure, and encephalopathy. ${ }^{8,44,83}$ Severe COVID-19 patients may have marked vascular dysfunction, which is seen in high levels of D-dimer and procoagulant factors. Thus, thromboembolic complications, including stroke, are commonly seen in these patients. ${ }^{84}$ The occurrence of stroke in COVID-19 patients has been reported in some studies. ${ }^{47,85}$ During SARS-CoV-2 infection, coagulopathy and inflammation can cause thrombosis in cerebral blood vessels and cardiac embolism, leading to ischemic stroke. The presence of pre-existing comorbidities, including advanced age, cardiovascular diseases, and cerebral microvascular dysfunction can be a significant risk factor for stroke in COVID-19 patients. ${ }^{86}$ Reports of meningoencephalitis ${ }^{87}$ and intracerebral hemorrhage in affected patients ${ }^{88}$ also indicate that the CNS is invaded by SARS-CoV-2.

Mao et al. ${ }^{47}$ were the first to report neurological injury in COVID-19 patients. This study included 214 patients from Wuhan, China, who were hospitalized and tested positive for SARS-CoV-2 infection. The neurological alterations were divided into manifestations of the CNS, peripheral nervous system, and skeletal muscle injury. A total of 78 patients $(36.4 \%)$ had neurological manifestations, of which $53(24.8 \%)$ were in the CNS, most often including dizziness (36 [16.8\%]) and headache (28 [13.1\%]). There were peripheral nervous system manifestations in 


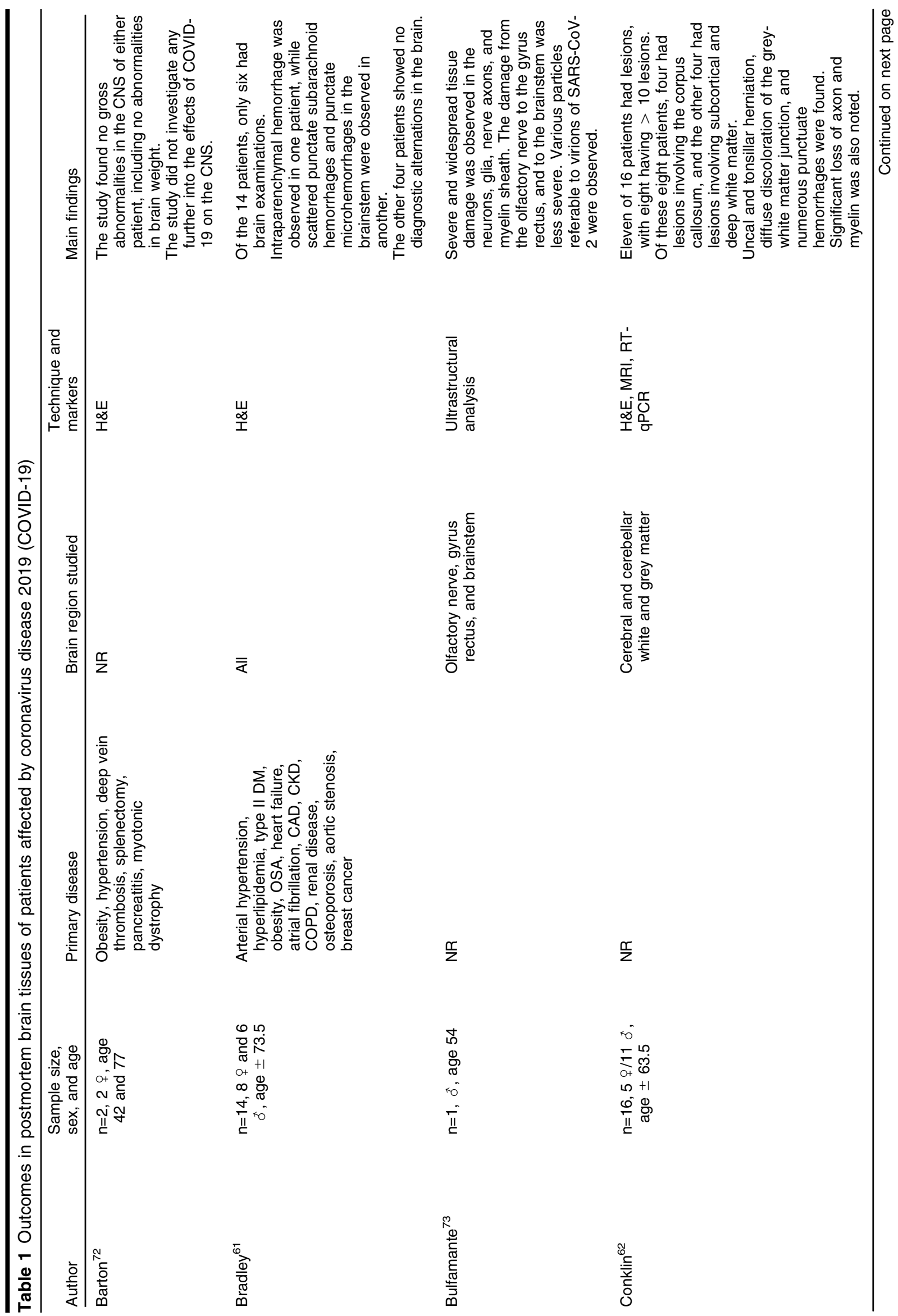




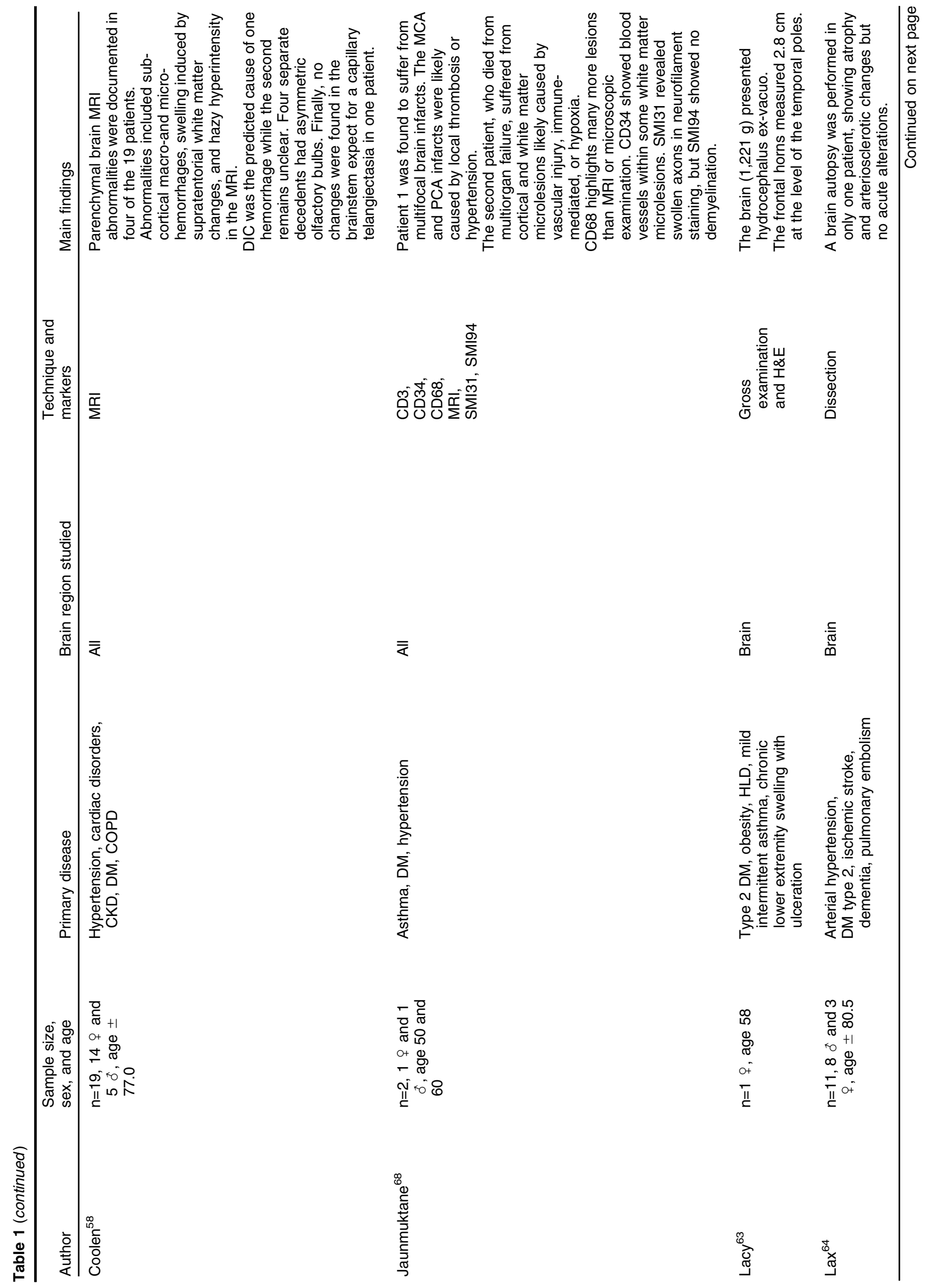



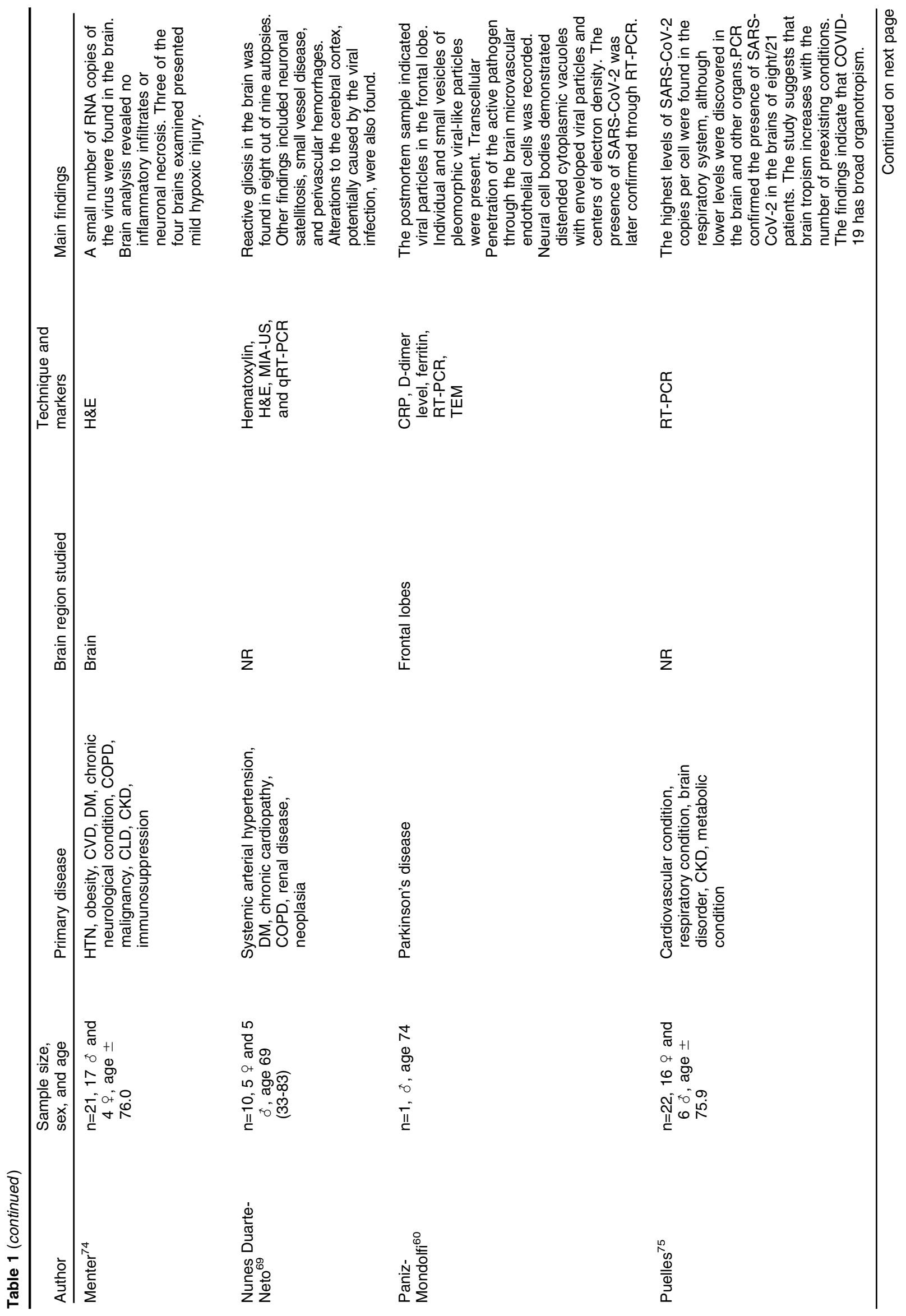

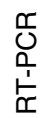

$\frac{\mathfrak{r}}{2}$

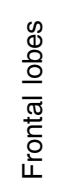

$\frac{n}{2}$

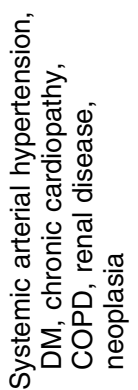

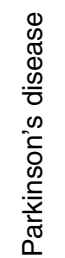
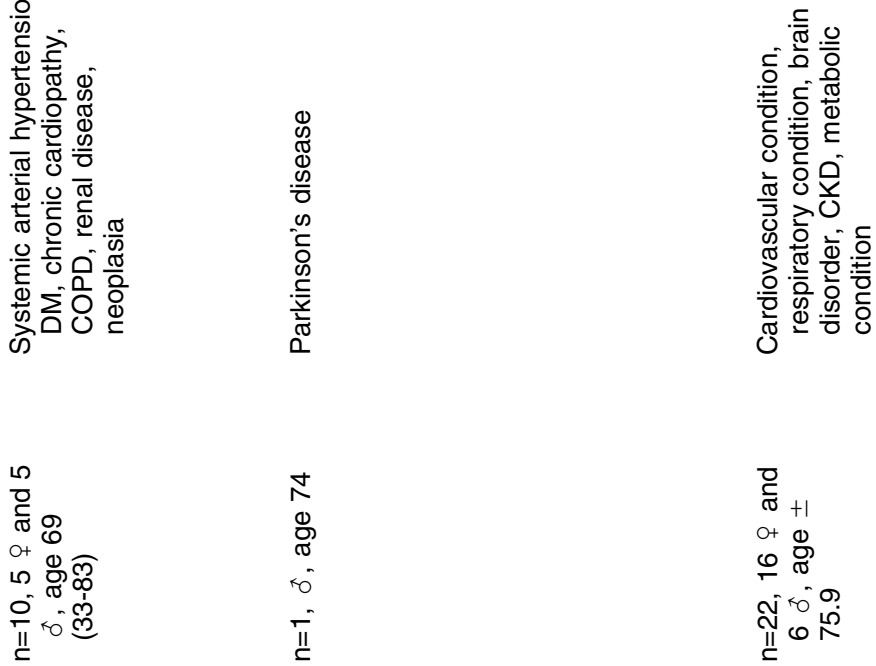

N
0
8
व
ro
II

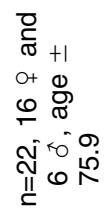

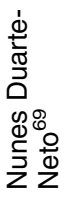

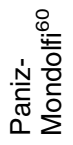

$\stackrel{2}{0}$
$\frac{d}{\bar{d}}$
$\frac{0}{2}$ 


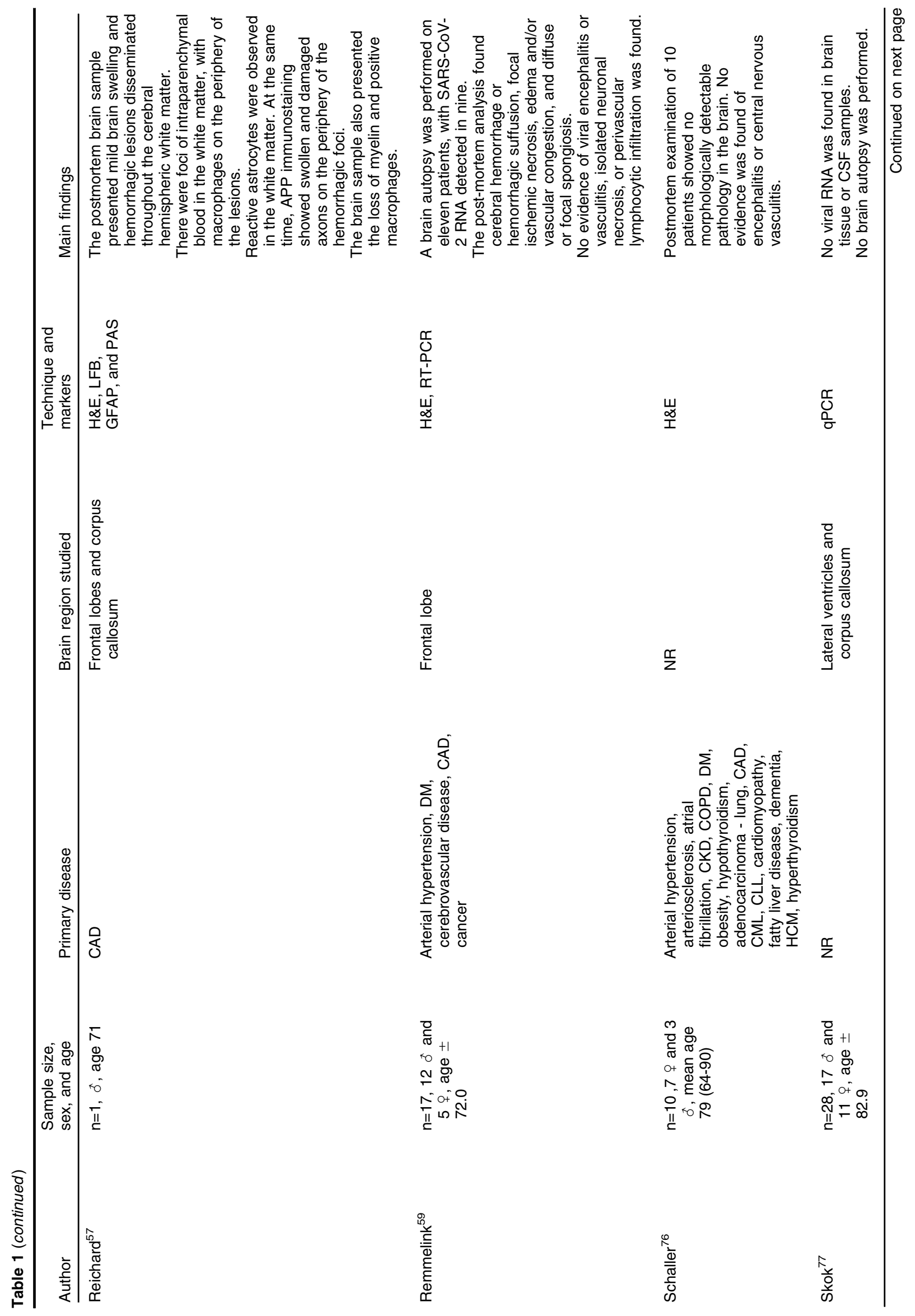




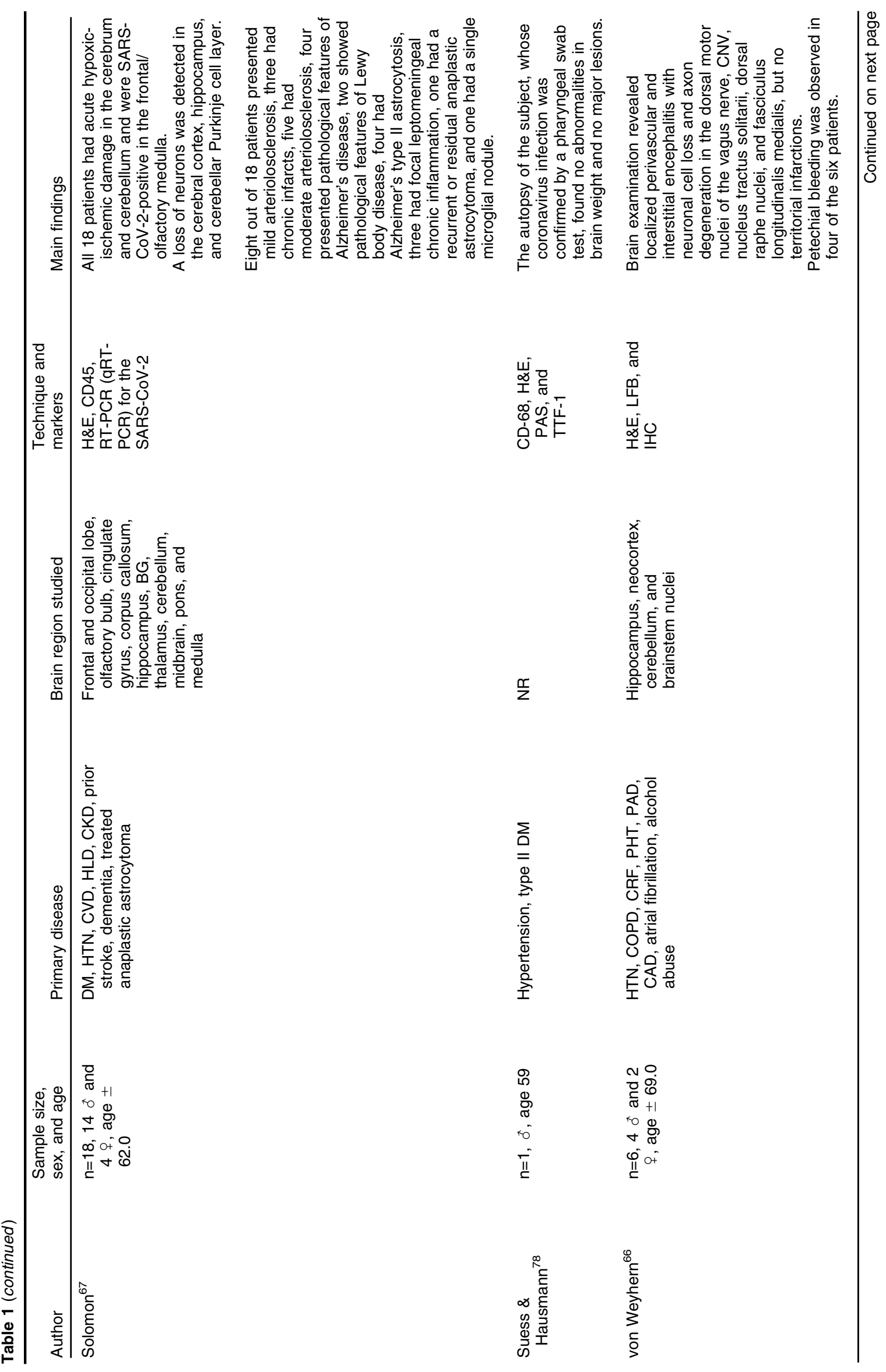




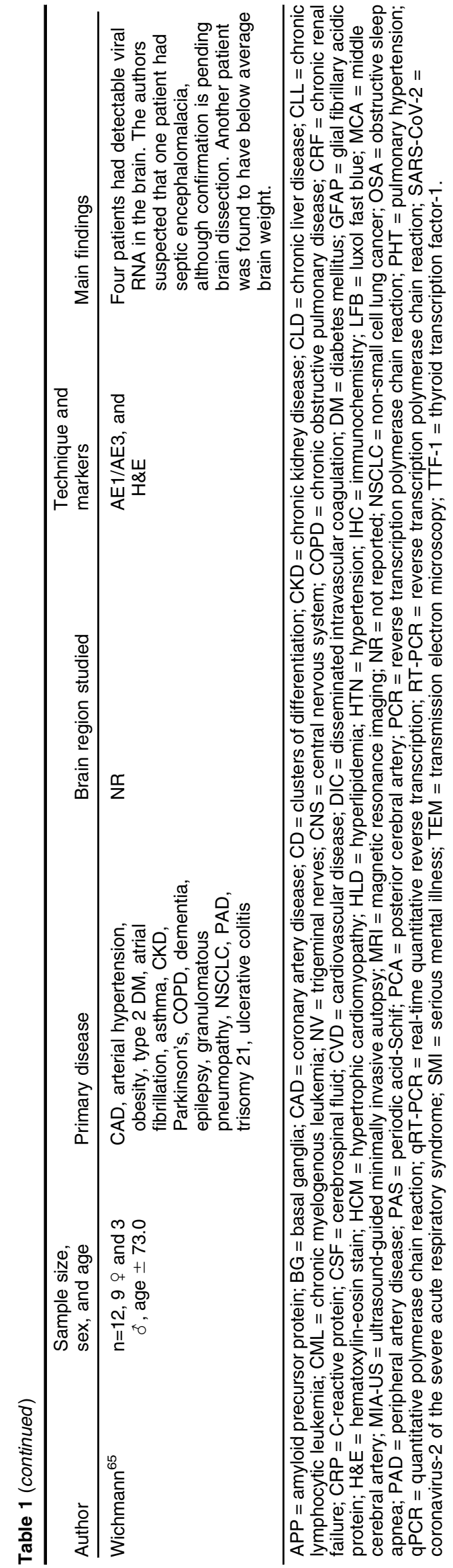

$19(8.9 \%)$, including ageusia (12 [5.6\%]) and anosmia (11 [5.1\%]). Twenty-three patients $(10.7 \%)$ had a skeletal muscle injury. Neurological manifestations were also more common in patients with severe infections and included acute cerebrovascular disease, impaired consciousness, and skeletal muscle injury, in addition to a more intense inflammatory response, lymphopenia, and increased levels of C-reactive protein. ${ }^{47}$ In another study with 60 patients affected by COVID-19, 41 (68.33\%) had neurological symptoms, including mood oscillation in $41.67 \%$, fatigue in $26.67 \%$, headache in $25 \%$, altered vision in $21.67 \%$, myalgia in $15 \%$, reduced mobility in $11.67 \%$, memory loss in $13.33 \%$, ageusia in $6.67 \%$, numbness in $6.67 \%$, tremors in $6.67 \%$, anosmia in $3.33 \%$, and hearing loss in $1.67 \%$. Three months after recovery, more than $50 \%$ of the patients still had neurological symptoms. ${ }^{89}$ Encephalitis, micro-hemorrhage, hemorrhage, encephalopathy, and cerebral venous embolism have also been reported as consequences of COVID-19 infection. $^{87,90}$ Zhang et al. ${ }^{91}$ evaluated 82 patients diagnosed with COVID-19 and found impaired consciousness in 17 (21\%). A case series study analyzed 27 patients under the age of 18. Neurological manifestations occurred in $14.8 \%$, such as encephalopathy, headache, brainstem signs with dysarthria or dysphagia, meningism and cerebellar ataxia, muscle weakness, and reduced reflexes. $^{92}$ A French study of 58 patients found that 40 $(69 \%)$ were agitated after sedation was discontinued, and confusion was observed in $26(65 \%)$ in the intensive care unit according to the Confusion Assessment Method. Some patients also had larger leptomeningeal spaces (13.62\%), and bilateral frontotemporal hypoperfusion was observed in eight patients. Two asymptomatic patients had small acute ischemic strokes, and one patient had a subacute ischemic stroke. Forty-five patients were evaluated after hospital discharge and 15 (33\%) showed inattention, disorientation or poorly organized movements in response to the command. ${ }^{93}$

\section{Psychiatric manifestations associated with coronavirus}

Several studies have addressed the impact of COVID-19 on mental health. Psychiatric manifestations can arise due to the direct effects of the virus entering the CNS or to the indirect effects of immune response, ${ }^{94}$ as well as to additional social stressors, which can contribute to the incidence and exacerbation of psychiatric disorders. ${ }^{95}$

Preclinical studies have shown an association between depressive-like behavior and high levels of tumor necrosis factor-alpha in the brain in an experimental model of pneumococcal meningitis. ${ }^{96,97}$ Persistent inflammatory response and behavioral deficits have been observed in adult offspring of female rats submitted to maternal immune activation, which suggests that inflammation could increase the risk of psychiatric disorders. ${ }^{98}$ In fact, previous studies support that immune response participates in the pathophysiology of mental illnesses such as depression, bipolar disorders, ${ }^{99-101}$ and suicidal behavior. ${ }^{102,103}$ Specifically regarding COVID-19, Ruan et al. ${ }^{104}$ showed that patients affected by the virus have high levels of inflammatory markers, which were predictors 
of mortality due to the disease. A potential link between inflammation due to COVID-19 and psychiatric manifestations has also been demonstrated in the literature. Gouse et al. ${ }^{105}$ reported a case in which a patient admitted with COVID-19 symptoms presented clinical signs of catatonia (mutism, posturing, staring, verbigeration, grimacing, echolalia, stereotypy, rigidity, waxy flexibility, automatic obedience, echolalia) along with peaking proinflammatory markers. Mazza et al. investigated the role of inflammatory markers in anxiety and depression among COVID-19 survivors. ${ }^{106} \mathrm{~A}$ total of 402 adults $(65.9 \%$ male, age range 18-87 years) with COVID-19 were assessed while in the emergency department (clinical and laboratory evaluation) and about 30 days after hospital treatment (psychiatric assessment). It was found that more than half of the patients presented psychiatric symptoms in the pathological range of at least one psychopathological dimension. Moreover, the baseline systemic immune-inflammation index (platelets $\times$ neutrophils/lymphocytes) was positively associated with depression and anxiety scores. ${ }^{106} \mathrm{~A}$ similar finding was reported by Hu et al., ${ }^{107}$ in which patients with COVID-19 presented a high frequency of depressive $(45.9 \%)$, anxiety $(38.8 \%)$, and insomnia $(54.1 \%)$ symptoms, which were positively and significantly associated with higher levels of IL-1 $\beta$.

The social stressors associated with the pandemic, including physical distancing as a mechanism to prevent its spread, financial issues, and the quarantine itself, can lead to an additional risk of psychiatric disorders. ${ }^{108}$ Biological, psychological, and sociocultural factors could also interact to determine the impact of the COVID-19 on mental health. ${ }^{109} \mathrm{~A}$ representative panel survey published by the Center for Surveillance, Epidemiology, and Laboratory Services of the U.S. Centers for Disease Control and Prevention reported an increase in the prevalence of anxiety disorder (approximately three times), depressive disorder (approximately four times), and suicidal ideation (approximately two times) during June $24-30,2020$ compared to previous years (2018 or 2019). ${ }^{110}$ Regarding the latter, the findings were remarkable among young adults (18-34 years old) and those who had not completed high school, with 25.5 and 30\%, respectively, reporting that had seriously considered suicide in the past 30 days. ${ }^{110}$ Krishnamoorthy et al. ${ }^{111}$ reviewed the prevalence of mental disorders, psychiatric symptoms, and mental distress among COVID-19 patients, healthcare workers, and the general population during the COVID-19 pandemic. The pooled effect size for patients with COVID-19 was larger than that of healthcare workers or the general population for depression $(42,25$, and $24 \%$, respectively), anxiety $(37,24$, and $26 \%$, respectively), post-traumatic stress symptoms (96, 13 , and $15 \%$, respectively), and poor sleep quality (82, 43 , and $34 \%$, respectively). ${ }^{111}$ Considering 12-month mood disorder and anxiety prevalences of 9.5 and $18.1 \%$, respectively, from a 2001-2003 U.S. survey, the rates reported by Krishnamoorthy et al. during the COVID-19 pandemic ${ }^{111}$ are substantial. ${ }^{112}$ The apparent higher risk of psychiatric disorders among patients with COVID-19 raises concerns about the safety of available treatments, especially pharmacological treatments. An international, multi-disciplinary working group of experts published evidence-based recommendations for the appropriate management of psychotropics in patients with COVID$19 .{ }^{113}$ It recommended special care regarding the potential interaction between COVID-19 treatments and psychotropic medications, the risk of respiratory depression, cardiovascular effects, and thromboembolism, in addition evaluating the dosage of patients currently in treatment. ${ }^{113}$ Clinicians should also consider evidencebased telehealth psychotherapeutic and psychoeducation interventions due to their efficacy and feasibility. ${ }^{114,115}$

In an editorial, da Silva et al. ${ }^{95,116}$ identified some mental health topics worthy of attention, including inadequate access to health services, especially in developing countries. A recent retrospective cohort study by Williams et al. ${ }^{117}$ showed that between March 1 and May 31, 2020, the first diagnosis of psychiatric problems was $50 \%$ lower than expected based on previous years, which suggests considerable underdiagnosis. The authors warned of a potential overload in the mental health system due to reduced access during the pandemic.

Longitudinal studies are necessary to evaluate the biological and environmental risk factors, as well as the protective interventions, that have shaped the impact of COVID-19 on mental health. Regarding protective factors, institutional support and resilience were found as mediators of the relationship between COVID-19-related stressors and psychological distress, which suggests the potential benefits of interventions that address both during a public health emergency. ${ }^{118}$ In a study of medical workers during the COVID-19 outbreak, resilience was negatively correlated with depression and anxiety and was positively correlated with active coping styles. ${ }^{119}$ Some programs have been implemented to build resilience, such as the Mount Sinai Center for Stress, Resilience, and Personal Growth, ${ }^{120}$ the Psychological Resilience Model, ${ }^{121}$ and CopeColumbia. ${ }^{122}$ Some of these initiatives include principles from psychotherapeutic interventions, such as cognitive-behavioral and acceptance and commitment therapies. Interestingly, a systematic review on the association between psychological interventions and immune system function found decreased proinflammatory cytokines and increased immune cell counts over time following treatment, especially for cognitive behavior therapy and multiple or combined psychosocial interventions. ${ }^{123}$ Moutier ${ }^{124}$ argues that this is a moment when evidence-based strategies for suicide prevention should be prioritized and maximized in the public health agenda at the community and federal levels. Despite the severe consequences associated with the pandemic, the knowledge acquired during this period can provide positive lessons for the field of mental health, both in terms of primary prevention and intervention. ${ }^{125}$

\section{Conclusion}

In conclusion, it must be pointed out that with the increasing number SARS-CoV-2 infections and the pandemic's potentially long-lasting social stressors, many patients will have neurological and psychiatric manifestations that could result 
in a considerable burden for these individuals, their families, and society. Psychiatric symptoms will not be limited only to patients affected by COVID-19, since environmental stressors are highly associated with the etiology and pathophysiology of psychiatric disorders. ${ }^{126,127}$

Although clinical and epidemiological studies and diagnosing brain disease associated with SARS-CoV-2 can be challenging, they are necessary to help define the COVID-19 burden during and after the pandemic.

\section{Acknowledgements}

The authors would like to thank Universidade do Extremo Sul Catarinense (UNESC), Conselho Nacional de Desenvolvimento Científico e Tecnológico (CNPq), and Fundação de Amparo à Pesquisa e Inovação de Santa Catarina (FAPESC). APD is supported by the Brain \& Behavior Research Foundation (NARSAD) Young Investigator Grant.

\section{Disclosure}

The authors report no conflicts of interest.

\section{References}

1 Gao GF. From "A"IV to "Z"IKV: attacks from emerging and reemerging pathogens. Cell. 2018;172:1157-9.

2 Weiss SR, Leibowitz JL. Coronavirus pathogenesis. In: Maramorosch K, Shatkin AJ, Murphy FA. Advances in virus research. Cambridge: Academic Press; 2011. p. 85-164.

3 Dawood FS, Ricks P, Njie GJ, Daugherty M, Davis W, Fuller JA, et al. Observations of the global epidemiology of COVID-19 from the prepandemic period using web-based surveillance: a crosssectional analysis. Lancet Infect Dis. 2020;20:1255-62.

4 World Health Organization (WHO). Pneumonia of unknown cause -China [Internte]. 2020 Jan 5 [cited 2020 Dec 14]. www.who.int/csr/ don/05-january-2020-pneumonia-of-unkown-cause-china/en/

5 Jasti M, Nalleballe K, Dandu V, Onteddu S. A review of pathophysiology and neuropsychiatric manifestations of COVID-19. J Neurol. 2020 Jun 3;1-6. doi: 10.1007/s00415-020-09950-w. Online ahead of print.

6 Zhu N, Zhang D, Wang W, Li X, Yang B, Song J, et al. A novel coronavirus from patients with pneumonia in China, 2019. N Engl $\mathrm{J}$ Med. 2020;382:727-33.

7 Coronaviridae Study Group of the International Committee on Taxonomy of Viruses. The species severe acute respiratory syndrome-related coronavirus: classifying 2019-nCoV and naming it SARS-CoV-2. Nat Microbiol. 2020;5:536-44.

8 Guan WJ, Ni ZY, Hu Y, Liang WH, Ou CQ, He JX, et al. Clinical characteristics of coronavirus disease 2019 in China. N Engl J Med. 2020;382:1708-20.

9 Eckerle I, Meyer B. SARS-CoV-2 seroprevalence in COVID-19 hotspots. Lancet. 2020;3:514-5.

10 Wiersinga WJ, Rhodes A, Cheng AC, Peacock SJ, Prescott HC. Pathophysiology, transmission, diagnosis, and treatment of coronavirus disease 2019 (COVID-19): a review. JAMA. 2020;324: 782-93.

11 Tang S, Mao Y, Jones RM, Tan Q, Ji JS, Li N, et al. Aerosol transmission of SARS-CoV-2? Evidence, prevention and control. Environ Int. 2020;144:106039.

12 Gandhi RT, Lynch JB, Del Rio C. Mild or moderate covid-19. N Engl J Med. 2020;383:1757-66.

13 Perico L, Benigni A, Casiraghi F, Ng LF, Renia L, Remuzzi G. Immunity, endothelial injury and complement-induced coagulopathy in COVID-19. Nat Rev Nephrol. 2021;17:46-64.

14 Huang C, Wang Y, Li X, Ren L, Zhao J, Hu Y, et al. Clinical features of patients infected with 2019 novel coronavirus in Wuhan, China. Lancet. 2020;395:497-506.
15 Wang D, Hu B, Hu C, Zhu F, Liu X, Zhang J, et al. Clinical characteristics of 138 hospitalized patients with 2019 novel coronavirusinfected pneumonia in Wuhan, China. JAMA. 2020;323:1061-9.

16 Wu C, Chen X, Cai Y, Xia J, Zhou X, Xu S, et al. Risk factors associated with acute respiratory distress syndrome and death in patients with coronavirus disease 2019 pneumonia in Wuhan, China. JAMA Intern Med. 2020;180:934-43.

17 Williamson EJ, Walker AJ, Bhaskaran K, Bacon S, Bates C, Morton $\mathrm{CE}$, et al. Factors associated with COVID-19-related death using OpenSAFELY. Nature. 2020;584:430-6.

18 Johns Hopkins University and Medicine, Coronavirus Resource Center. COVID-19 Dashboard by the Center for Systems Science and Engineering (CSSE) at Johns Hopkins University and Medicine [Internet]. [cited 2020 Dec 14]. coronavirus.jhu.edu/map.html

19 World Health Organization (WHO). Coronavirus disease (COVID19) - weekly epidemiological update [Internet]. 2020 Dec 1 [cited 2020 Dec 14]. www.who.int/publications/m/item/weekly-epidemio logical-update---1-december-2020

20 Cui J, Li F, Shi ZL. Origin and evolution of pathogenic coronaviruses. Nat Rev Microbiol. 2019;17:181-92.

21 Petersen E, Koopmans M, Go U, Hamer DH, Petrosillo N, Castelli F, et al. Comparing SARS-CoV-2 with SARS-CoV and influenza pandemics. Lancet Infect Dis. 2020;20:e238-44.

22 Kim D, Lee JY, Yang JS, Kim JW, Kim VN, Chang H. The architecture of SARS-CoV-2 transcriptome. Cell. 2020;181:914-21.e10.

23 Chen B, Tian EK, He B, Tian L, Han R, Wang S, et al. Overview of lethal human coronaviruses. Signal Transduc Target Ther. 2020;5:89.

24 Lu R, Zhao X, Li J, Niu P, Yang B, Wu H, et al. Genomic characterisation and epidemiology of 2019 novel coronavirus: implications for virus origins and receptor binding. Lancet. 2020;395:565-74

25 Jiang S, Hillyer C, Du L. Neutralizing antibodies against SARSCoV-2 and other human coronaviruses: (Trends in Immunology 41, 355-359; 2020). Trends Immunol. 2020;41:545.

26 Goldsmith CS, Tatti KM, Ksiazek TG, Rollin PE, Comer JA, et al. Ultrastructural characterization of SARS coronavirus. Emerg Infect Dis. 2004;10:320-6.

27 Walls AC, Park YJ, Tortorici MA, Wall A, McGuire AT, Veesler D. Structure, function, and antigenicity of the SARS-CoV-2 spike glycoprotein. Cell. 2020;181:281-92.6.

28 Zhou P, Yang XL, Wang XG, Hu B, Zhang L, Zhang W, et al. A pneumonia outbreak associated with a new coronavirus of probable bat origin. Nature. 2020;579:270-3.

29 Beniac DR, Andonov A, Grudeski E, Booth TF. Architecture of the SARS coronavirus prefusion spike. Nat Struct Mol Biol. 2006;13: 751-2.

30 Astuti I, Ysrafil. Severe acute respiratory syndrome coronavirus 2 (SARS-CoV-2): an overview of viral structure and host response. Diabetes Metab Syndr. 2020;14:407-12.

31 Chang CK, Sue SC, Yu TH, Hsieh CM, Tsai CK, Chiang YC, et al. Modular organization of SARS coronavirus nucleocapsid protein. J Biomed Sci. 2006;13:59-72.

32 Scheller C, Krebs F, Minkner R, Astner I, Gil-Moles M, Wätzig H. Physicochemical properties of SARS-CoV-2 for drug targeting, virus inactivation and attenuation, vaccine formulation and quality control. Electrophoresis. 2020;41:1137-51.

33 Fehr AR, Perlman S. Coronaviruses: an overview of their replication and pathogenesis. Methods Mol Biol. 2015;1282:1-23.

34 Liu W, Liu L, Kou G, Zheng Y, Ding Y, Ni W, et al. Evaluation of nucleocapsid and spike protein-based enzyme-linked immunosorbent assays for detecting antibodies against SARS-CoV-2. J Clin Microbiol. 2020;58:e00461-20.

35 Tai W, He L, Zhang X, Pu J, Voronin D, Jiang S, et al. Characterization of the receptor-binding domain (RBD) of 2019 novel coronavirus: implication for development of RBD protein as a viral attachment inhibitor and vaccine. Cell Mol Immunol. 2020;17:613-20.

36 Malik YA. Properties of coronavirus and SARS-CoV-2. Malays J Pathol. 2020;42:3-11.

37 Schoeman D, Fielding BC. Coronavirus envelope protein: current knowledge. Virol J. 2019;16:69.

38 Pervushin K, Tan E, Parthasarathy K, Lin X, Jiang FL, Yu D, et al. Structure and inhibition of the SARS coronavirus envelope protein ion channel. PLoS Pathog. 2009;5:e1000511.

39 Yuki K, Fujiogi M, Koutsogiannaki S. COVID-19 pathophysiology: a review. Clin Immunol. 2020;215:108427. 
40 Wadman M, Couzin-Frankel F, Kaiser J, Matacic C. How does coronavirus kill? Clinicians trace a ferocious rampage through the body, from brain to toes [Internet]. 2020 Apr 17 [cited 2020 Dec 14]. www.sciencemag.org/news/2020/04/how-does-coronavirus-kill-clin icians-trace-ferocious-rampage-through-body-brain-toes

41 Oxley TJ, Mocco J, Majidi S, Kellner CP, Shoirah H, Singh IP, et al. Large-vessel stroke as a presenting feature of covid-19 in the young. N Engl J Med. 2020;382:e60.

42 Florindo HF, Kleiner R, Vaskovich-Koubi D, Acúrcio RC, Carreira B, Yeini E, et al. Immune-mediated approaches against COVID-19. Nat Nanotechnol. 2020;15:630-45.

43 Xia H, Lazartigues E. Angiotensin-converting enzyme 2 in the brain: properties and future directions. J Neurochem. 2008;107: 1482-94.

44 Zubair AS, McAlpine LS, Gardin T, Farhadian S, Kuruvilla DE, Spudich S. Neuropathogenesis and neurologic manifestations of the coronaviruses in the age of coronavirus disease 2019: a review. JAMA Neurol. 2020;77:1018-27.

45 Postolache TT, Benros ME, Brenner LA. Targetable biological mechanisms implicated in emergent psychiatric conditions associated with SARS-CoV-2 infection. JAMA Psychiatry. 2020 Jul 31. doi: 10.1001/jamapsychiatry.2020.2795. Online ahead of print.

46 Desforges M, Le Coupanec A, Dubeau P, Bourgouin A, Lajoie L, Dubé $M$, et al. Human coronaviruses and other respiratory viruses: underestimated opportunistic pathogens of the central nervous system? Viruses. 2019;12:14.

47 Mao L, Jin H, Wang M, Hu Y, Chen S, He Q, et al. Neurologic manifestations of hospitalized patients with coronavirus disease 2019 in Wuhan, China. JAMA Neurol. 2020;77:683-90.

48 Li YC, Bai WZ, Hashikawa T. The neuroinvasive potential of SARSCoV2 may play a role in the respiratory failure of COVID-19 patients. J Med Virol. 2020;92:552-5.

49 Hoffmann M, Kleine-Weber H, Schroeder S, Krüger N, Herrler T, Erichsen S, et al. SARS-CoV-2 cell entry depends on ACE2 and TMPRSS2 and is blocked by a clinically proven protease inhibitor. Cell. 2020;181:271-80.e8.

50 Akira S, Uematsu S, Takeuchi O. Pathogen recognition and innate immunity. Cell. 2006;124:783-801.

51 Mook-Kanamori BB, Geldhoff M, van der Poll T, van de Beek D. Pathogenesis and pathophysiology of pneumococcal meningitis. Clin Microbiol Rev. 2011;24:557-91.

52 Li G, Fan Y, Lai Y, Han T, Li Z, Zhou P, et al. Coronavirus infections and immune responses. J Med Virol. 2020;92:424-32.

53 Cohen J. The immunopathogenesis of sepsis. Nature. 2002;420: 885-91.

54 de Wit E, van Doremalen N, Falzarano D, Munster VJ. SARS and MERS: recent insights into emerging coronaviruses. Nat Rev Microbiol. 2016;14:523-34.

55 Prompetchara E, Ketloy C, Palaga T. Immune responses in COVID19 and potential vaccines: lessons learned from SARS and MERS epidemic. Asian Pac J Allergy Immunol. 2020;38:1-9.

56 Li X, Geng M, Peng Y, Meng L, Lu S. Molecular immune pathogenesis and diagnosis of COVID-19. J Pharm Anal. 2020;10:102-8.

57 Reichard RR, Kashani KB, Boire NA, Constantopoulos E, Guo Y, Lucchinetti CF. Neuropathology of COVID-19: a spectrum of vascular and acute disseminated encephalomyelitis (ADEM)-like pathology. Acta Neuropathol. 2020;140:1-6.

58 Coolen T, Lolli V, Sadeghi N, Rovai A, Trotta N, Taccone FS, et al. Early postmortem brain MRI findings in COVID-19 non-survivors. Neurology. 2020;95:e2016-e27.

59 Remmelink M, De Mendonça R, D’Haene N, De Clercq S, Verocq C, Lebrun L, et al. Unspecific post-mortem findings despite multiorgan viral spread in COVID-19 patients. Crit Care. 2020;24:495.

60 Paniz-Mondolfi A, Bryce C, Grimes Z, Gordon RE, Reidy J, Lednicky $J$, et al. Central nervous system involvement by severe acute respiratory syndrome coronavirus-2 (SARS-CoV-2). J Med Virol. 2020;92:699-702.

61 Bradley BT, Maioli H, Johnston R, Chaudhry I, Fink SL, Xu H, et al. Histopathology and ultrastructural findings of fatal COVID-19 infections in Washington State: a case series. Lancet. 2020;396:320-32.

62 Conklin J, Frosch MP, Mukerji S, Rapalino O, Maher M, Schaefer PW, et al. Cerebral microvascular injury in severe COVID-19. medRxiv. 2020 Jul 24;2020.07.21.20159376. doi: 10.1101/2020. 07.21.20159376. Preprint
63 Lacy JM, Brooks EG, Akers J, Armstrong D, Decker L, Gonzalez A, et al. COVID-19: postmortem diagnostic and biosafety considerations. Am J Forensic Med Pathol. 2020;41:143-51.

64 Lax SF, Skok K, Zechner P, Kessler HH, Kaufmann N, Koelblinger C, et al. Pulmonary arterial thrombosis in COVID-19 with fatal outcome: results from a prospective, single-center, clinicopathologic case series. Ann Intern Med. 2020;173:350-61.

65 Wichmann D, Sperhake JP, Lütgehetmann M, Steurer S, Edler C, Heinemann A, et al. Autopsy findings and venous thromboembolism in patients with COVID-19. Ann Intern Med. 2020;173:268-77.

66 von Weyhern $\mathrm{CH}$, Kaufmann I, Neff F, Kremer M. Early evidence of pronounced brain involvement in fatal COVID-19 outcomes. Lancet. 2020;395:e109.

67 Solomon IH, Normandin E, Bhattacharyya S, Mukerji SS, Keller K, Ali AS, et al. Neuropathological features of Covid-19. N Engl J Med. 2020;383:989-92.

68 Jaunmuktane Z, Mahadeva U, Green A, Sekhawat V, Barrett NA, Childs $L$, et al. Microvascular injury and hypoxic damage: emerging neuropathological signatures in COVID-19. Acta Neuropathol. 2020;140:397-400.

69 Duarte-Neto AN, Monteiro RA, da Silva LF, Malheiros DM, de Oliveira EP, Theodoro-Filho J, et al. Pulmonary and systemic involvement of COVID-19 assessed by ultrasound-guided minimally invasive autopsy. Histopathology. 2020;77:186-97.

70 Menter T, Haslbauer JD, Nienhold R, Savic S, Hopfer H, Deigendesch $\mathrm{N}$, et al. Postmortem examination of COVID-19 patients reveals diffuse alveolar damage with severe capillary congestion and variegated findings in lungs and other organs suggesting vascular dysfunction. Histopathology. 2020;77:198-208.

71 Solomon IH, Normandin E, Bhattacharyya S, Mukerji SS, Keller K, Ali AS, et al. Neuropathological features of Covid-19. N Engl J Med. 2020;383:989-92.

72 Barton LM, Duval EJ, Stroberg E, Ghosh S, Mukhopadhyay S. COVID-19 autopsies, Oklahoma, USA. Am J Clin Pathol. 2020;153: 725-33.

73 Bulfamante G, Chiumello D, Canevini MP, Priori A, Mazzanti M, Centanni S, et al. First ultrastructural autoptic findings of SARS -Cov-2 in olfactory pathways and brainstem. Minerva Anestesiol. 2020;86:678-9.

74 Menter T, Haslbauer JD, Nienhold R, Savic S, Hopfer H, Deigendesch $\mathrm{N}$, et al. Postmortem examination of COVID-19 patients reveals diffuse alveolar damage with severe capillary congestion and variegated findings in lungs and other organs suggesting vascular dysfunction. Histopathology. 2020;77:198-209.

75 Puelles VG, Lütgehetmann M, Lindenmeyer MT, Sperhake JP, Wong MN, Allweiss L, et al. Multiorgan and renal tropism of SARSCoV-2. N Engl J Med. 2020;383:590-2.

76 Schaller T, Hirschbühl K, Burkhardt K, Braun G, Trepel M, Märkl B, et al. Postmortem examination of patients with COVID-19. JAMA. 2020;323:2518-20.

77 Skok K, Stelzl E, Trauner M, Kessler HH, Lax SF. Post-mortem viral dynamics and tropism in COVID-19 patients in correlation with organ damage. Virchows Arch. 2020 Aug 20;1-11. doi: 10.1007/ s00428-020-02903-8. Online ahead of print.

78 Suess C, Hausmann R. Gross and histopathological pulmonary findings in a COVID-19 associated death during self-isolation. Int $\mathrm{J}$ Legal Med. 2020;134:1285-90.

79 Ellul MA, Benjamin L, Singh B, Lant S, Michael BD, Easton A, et al. Neurological associations of COVID-19. Lancet Neurol. 2020;19:767-83.

80 Winkler AS, Knauss S, Schmutzhard E, Leonardi M, Padovani A, Abd-Allah F, et al. A call for a global COVID-19 Neuro Research Coalition. Lancet Neurol. 2020;19:482-4.

81 Romero-Sánchez CM, Díaz-Maroto I, Fernández-Díaz E, SánchezLarsen A, Layos-Romero A, García-García J, et al. Neurologic manifestations in hospitalized patients with COVID-19: the ALBACOVID registry. Neurology. 2020;95:e1060-e70.

82 Varga Z, Flammer AJ, Steiger P, Haberecker M, Andermatt R, Zinkernagel AS, et al. Endothelial cell infection and endotheliitis in COVID-19. Lancet. 2020;395:1417-8.

83 Nalleballe K, Onteddu SR, Sharma R, Dandu V, Brown A, Jasti M, et al. Spectrum of neuropsychiatric manifestations in COVID-19. Brain Behav Immun. 2020;88:71-4.

84 Beyrouti R, Adams ME, Benjamin L, Cohen H, Farmer SF, Goh YY, et al. Characteristics of ischaemic stroke associated with COVID-19. J Neurol Neurosurg Psychiatry. 2020;91:889-91. 
85 Yaghi S, Ishida K, Torres J, Mac Grory B, Raz E, Humbert K, et al. SARS-CoV-2 and stroke in a New York healthcare system. Stroke. 2020;51:2002-11.

86 Singhal AB, Gonzalez RG, Chwalisz BK, Mukerji SS. Case 26-2020: a 60-year-old woman with altered mental status and weakness on the left side. N Engl J Med. 2020;383:764-73.

87 Huang $\mathrm{YH}$, Jiang D, Huang JT. SARS-CoV-2 detected in cerebrospinal fluid by PCR in a case of COVID-19 encephalitis. Brain Behav Immun. 2020;87:149.

88 Sharifi-Razavi A, Karimi N, Rouhani N. COVID-19 and intracerebral haemorrhage: causative or coincidental? New Microbes New Infect. 2020;35:100669.

89 Lu Y, Li X, Geng D, Mei N, Wu PY, Huang CC, et al. Cerebral microstructural changes in COVID-19 patients -- an MRI-based 3-month follow-up study. EClinicalMedicine. 2020;25:100484.

90 Baig AM. Updates on what ACS reported: emerging evidences of COVID-19 with nervous system involvement. ACS Chem Neurosci. 2020;11:1204-5.

91 Zhang B, Zhou X, Qiu Y, Song Y, Feng F, Feng J, et al. Clinical characteristics of 82 death cases with COVID-19. PLoS One. 2020;15:e0235458.

92 Abdel-Mannan O, Eyre M, Löbel U, Bamford A, Eltze C, Hameed B, et al. Neurologic and radiographic findings associated with COVID19 infection in children. JAMA Neurol. 2020;77:1-6.

93 Helms J, Kremer S, Merdji H, Clere-Jehl R, Schenck M, Kummerlen $\mathrm{C}$, et al. Neurologic features in severe SARS-CoV-2 infection. N Engl J Med. 2020;382:2268-70.

94 Pfefferbaum B, North CS. Mental health and the Covid-19 pandemic. N Engl J Med. 2020;383:510-2.

95 da Silva AG, Miranda DM, Diaz AP, Teles AL, Malloy-Diniz LF, Palha AP. Mental health: why it still matters in the midst of a pandemic. Braz J Psychiatry. 2020;42:229-31.

96 Barichello T, Simões LR, Generoso JS, Sharin VS, Souza LB, Jornada LK, et al. Depression-like adult behaviors may be a longterm result of experimental pneumococcal meningitis in wistar rats infants. Neurochem Res. 2016;41:2771-8.

97 Barichello T, Milioli G, Generoso JS, Cipriano AL, Costa CS, Moreira $\mathrm{AP}$, et al. Imipramine reverses depressive-like parameters in pneumococcal meningitis survivor rats. J Neural Transm (Vienna). 2012;119:653-60.

98 Simoes LR, Sangiogo G, Tashiro MH, Generoso JS, Faller CJ, Dominguini $\mathrm{D}$, et al. Maternal immune activation induced by lipopolysaccharide triggers immune response in pregnant mother and fetus, and induces behavioral impairment in adult rats. J Psychiatr Res. 2018;100:71-83.

99 Sayana P, Colpo GD, Simões LR, Giridharan VV, Teixeira AL, Quevedo $\mathrm{J}$, et al. A systematic review of evidence for the role of inflammatory biomarkers in bipolar patients. J Psychiatr Res. 2017;92:160-82.

100 Köhler-Forsberg O, Lydholm CN, Hjorthøj C, Nordentoft M, Mors O, Benros ME. Efficacy of anti-inflammatory treatment on major depressive disorder or depressive symptoms: meta-analysis of clinical trials. Acta Psychiatr Scand. 2019;139:404-19.

101 lob E, Lacey R, Steptoe A. Adverse childhood experiences and depressive symptoms in later life: longitudinal mediation effects of inflammation. Brain Behav Immun. 2020;90:97-107.

102 Black C, Miller BJ. Meta-analysis of cytokines and chemokines in suicidality: distinguishing suicidal versus nonsuicidal patients. Biol Psychiatry. 2015;78:28-37.

103 Melhem NM, Munroe S, Marsland A, Gray K, Brent D, Porta G, et al. Blunted HPA axis activity prior to suicide attempt and increased inflammation in attempters. Psychoneuroendocrinology. 2017;77: 284-94.

104 Ruan Q, Yang K, Wang W, Jiang L, Song J. Clinical predictors of mortality due to COVID-19 based on an analysis of data of 150 patients from Wuhan, China. Intensive Care Med. 2020;46:846-8.

105 Gouse BM, Spears WE, Archibald AN, Montalvo C. Catatonia in a hospitalized patient with COVID-19 and proposed immune-mediated mechanism. Brain Behav Immun. 2020;89:529-30.

106 Mazza MG, De Lorenzo R, Conte C, Poletti S, Vai B, Bollettini I, et al. Anxiety and depression in COVID-19 survivors: role of inflammatory and clinical predictors. Brain Behav Immun. 2020;89:594-600.

$107 \mathrm{Hu}$ Y, Chen Y, Zheng Y, You C, Tan J, Hu L, et al. Factors related to mental health of inpatients with COVID-19 in Wuhan, China Brain Behav Immun. 2020;89:587-93.
108 Rogers JP, Chesney E, Oliver D, Pollak TA, McGuire P, FusarPoli $P$, et al. Psychiatric and neuropsychiatric presentations associated with severe coronavirus infections: a systematic review and meta-analysis with comparison to the COVID-19 pandemic. Lancet Psychiatry. 2020;7:611-27

109 Silva RM, Shavitt RG, Costa DL. Obsessive-compulsive disorder during the COVID-19 pandemic. Braz J Psychiatry. 2021;43:108.

110 Czeisler ME, Lane RI, Petrosky E, Wiley JF, Christensen A, Njai R et al. Mental health, substance use, and suicidal ideation during the COVID-19 pandemic - United States, June 24-30, 2020. MMWR Morb Mortal Wkly Rep. 2020;69:1049-57.

111 Krishnamoorthy Y, Nagarajan R, Saya GK, Menon V. Prevalence of psychological morbidities among general population, healthcare workers and COVID-19 patients amidst the COVID-19 pandemic: a systematic review and meta-analysis. Psychiatry Res. 2020;293: 113382.

112 Kessler RC, Chiu WT, Demler O, Merikangas KR, Walters EE. Prevalence, severity, and comorbidity of 12-month DSM-IV disorders in the National Comorbidity Survey Replication. Arch Gen Psychiatry. 2005;62:617-27.

113 Ostuzzi G, Papola D, Gastaldon C, Schoretsanitis G, Bertolini F, Amaddeo F, et al. Safety of psychotropic medications in people with COVID-19: evidence review and practical recommendations. BMC Med. 2020;18:215

114 Rotenberg LS, Nascimento C, Cohab Khafif T, Dias RS, Lafer B. Psychological therapies and psychoeducational recommendations for bipolar disorder treatment during COVID-19 pandemic. Bipolar Disord. 2020;22:644-6.

115 Shore JH, Schneck CD, Mishkind MC. Telepsychiatry and the Coronavirus disease 2019 pandemic-current and future outcomes of the rapid virtualization of psychiatric care. JAMA Psychiatry. 2020 May 11. doi: 10.1001/jamapsychiatry.2020.1643. Online ahead of print.

116 Gonzalez-Diaz JM, Lozano-Lesmes L, Campo-Arias A. Comment on "Mental health: why it still matters in the midst of a pandemic". Braz J Psychiatry. 2020;42:451.

117 Williams R, Jenkins DA, Ashcroft DM, Brown B, Campbell S, Carr MJ, et al. Diagnosis of physical and mental health conditions in primary care during the COVID-19 pandemic: a retrospective cohort study. Lancet Public Health. 2020;5:e543-e50.

118 Tam CC, Sun S, Yang X, Li X, Zhou Y, Shen Z. Psychological distress among hiv healthcare providers during the COVID-19 pandemic in China: mediating roles of institutional support and resilience. AIDS Behav. 2020 Oct 21;1-9. doi: 10.1007/s10461-02003068-w. Online ahead of print.

119 Lin J, Ren YH, Gan HJ, Chen Y, Huang YF, You XM. Factors associated with resilience among non-local medical workers sent to Wuhan, China during the COVID-19 outbreak. BMC Psychiatry. 2020;20:417.

120 DePierro J, Katz CL, Marin D, Feder A, Bevilacqua L, Sharma V, et al. Mount Sinai's Center for Stress, Resilience and Personal Growth as a model for responding to the impact of COVID-19 on health care workers. Psychiatry Res. 2020;293:113426.

$121 \mathrm{He}$ Z, Chen J, Pan K, Yue Y, Cheung T, Yuan Y, et al. The development of the 'COVID-19 Psychological Resilience Model' and its efficacy during the COVID-19 pandemic in China. Int $\mathrm{J}$ Biol Sci. 2020;16:2828-34.

122 Mellins CA, Mayer LE, Glasofer DR, Devlin MJ, Albano AM, Nash SS, et al. Supporting the well-being of health care providers during the COVID-19 pandemic: the CopeColumbia response. Gen Hosp Psychiatry. 2020;67:62-9.

123 Shields GS, Spahr CM, Slavich GM. Psychosocial interventions and immune system function: a systematic review and meta-analysis of randomized clinical trials. JAMA Psychiatry. 2020;77:1031-43.

124 Moutier C. Suicide prevention in the COVID-19 era: transforming threat into opportunity. JAMA Psychiatry. 2020 Oct 16. doi: 10.1001/ jamapsychiatry.2020.3746. Online ahead of print

125 Moreno C, Wykes T, Galderisi S, Nordentoft M, Crossley N, Jones $\mathrm{N}$, et al. How mental health care should change as a consequence of the COVID-19 pandemic. Lancet Psychiatry. 2020;7:813-24.

126 Tsuang MT, Bar JL, Stone WS, Faraone SV. Gene-environment interactions in mental disorders. World Psychiatry. 2004;3: 73-83.

127 Uher R, Zwicker A. Etiology in psychiatry: embracing the reality of poly-gene-environmental causation of mental illness. World Psychiatry. 2017;16:121-9. 